\title{
PENINGKATAN KECERDASAN EMOSIONAL MELALUI SHOLAT FARDU BERJAMAAH MAHASISWA FAKULTAS TARBIYAH DAN ILMU KEGURUAN DI MASJID KAMPUS AR-ROBBANIYIN UNISNU JEPARA
}

\author{
Mufid $^{1)}$, Alex Yusron Al-Mufti²) \\ 1,2Universitas Islam Nahdlatul Ulama Jepara \\ ${ }^{1}$ mufidnabila@gmail.com \\ 2goesxela@gmail.com
}

\begin{abstract}
ABSTRAK
Penelitian ini bertujuan untuk mengetahui sejauh mana kebiasaan sholat fardlu berjamaah di masjid kampus Universitas Islam Nahdlatul Ulama Jepara berpengaruh terhadap kecerdasan emosional mahasiswa fakultas tarbiyah dan ilmu keguruan. Penelitian ini menggunakan pendekatan kualitatif deskriptif dengan menggunakan instrumen kuisioner, deep interview, dan observasi dengan menggunakan teknik purpose sampling dalam pengambilan sampel penelitian. Di dalam penelitian ini terbukti bahwa kebiasaan sholat berjamaah ternyata berpengaruh positif terhadap kecerdasan emosional. Dengan masing-masing item pertanyaan bobot 100\%, diperoleh data sebagai berikut: Mampu mengendalikan dorongan nafsu duniawi $66 \%$, memotivasi diri sendiri 86,6\%, mampu bertahan dalam menghadapi cobaan $80 \%$, tidak melebih-lebihkan kesenangan 86,6\%, mampu mengatur suasana hati 83,3\%, menjaga agar beban stress tidak melumpuhkan kemampuan berpikir $86,67 \%$, berempati dan berdoa 76,6 \%. Penelitian ini membuktikan bahwa kecerdasan emosional seseorang dapat ditingkatkan dengan salah satunya mewajibkan anak-anak di lingkungan pendidikan baik madrasah, sekolah, perguruan tinggi, serta berbagai lembaga pendidikan untuk mewajibkan kepada peserta didiknya melaksanakan sholat berjamaah sebagai salah satu upaya menambah kecerdasan emosional anak.
\end{abstract}

Kata Kunci: sholat fardlu berjamaah, kecerdasan emosional, fakultas tarbiyah dan ilmu keguruan Unisnu Jepara

\footnotetext{
ABSTRACT

This research aims to study how the custom of Fardlu prayer in congregation at the mosque of the Nahdlatul Ulama Islamic University in Jepara supports the emotional intelligence of Tarbiyah faculty and teacher science students. This study used a qualitative descriptive study using questionnaire instruments, in-depth interviews, and observations using purpose sampling techniques by taking research samples. In this study, it
} 
was proven that the habit of praying in congregation proved to have a positive effect on emotional intelligence. With each item question weighting $100 \%$, the following data were obtained: Able to increase worldly impulse $66 \%$, motivate yourself $86.6 \%$, able to endure trying $80 \%$ trials, unsuccessfully-get pleasure $86.6 \%$, able $83.3 \%$, stress load so as not to paralyze the ability to think $86.67 \%$, empathize and pray $76.6 \%$. This research proves someone's emotional intelligence can help him improve the problem of children's education in madrasah education schools, schools, colleges, and various educational institutions to interview students to carry out congregational prayer as one of the aids to improve children's emotional intelligence.

Keywords: Fardlu prayer in congregation, emotional intelligence, tarbiyah and teacher training faculty of Unisnu Jepara 


\section{PENDAHULUAN}

Sesungguhnya manusia di ciptakan oleh Allah SWT di dunia ini dengan diberikan berbagai macam kelebihan. Diantara kelebihan yang diberikan kepada manusia adalah berupa bakat dan kecerdasan. Banyak bakat yang dimiliki manusia yang harus dididik dengan multi talent approach. Manusia juga diberikan berbagai macam kecerdasan, antara lain kecerdasan intelektual, emotional, moral dan spiritual.

Dari berbagai macam kecerdasan tersebut, ternyata kurang dioptimalkan oleh manusia dengan sepenuhnya. Bahkan dalam rentang waktu dan sejarah yang panjang, manusia hanya mengagungkan kemampuan otak dan daya nalar (IQ). Kemampuan berpikir dianggap sebagai primadona, bahkan diklaim sebagai "dewa", konsekuensinya, potensi diri manusia yang lain dianggap inferior dan bahkan dimarjinalkan. Pola pikir dan cara pandang yang demikian telah melahirkan manusia yang terdidik degan otak yang cerdas, tetapi sikap dan perilaku, dan pola hidupnya sangat kontras dengan kemampuan intelektualnya. Banyak orang yang cerdas akademik, tetapi gagal dalam pekerjaan dan kehidupan sosialnya. Mereka memiliki kepribadian yang terbelah (split personality) sehingga tidak terjadi integrasi antara otak dan hati. Kondisi tersebut pada gilirannya menimbulkan krisis multidimensi yang sangat memperihatinkan.

Fenomena tersebut telah menyadarkan para pakar bahwa kesuksesan seseorang tidak hanya ditentukan oleh kemampuan otak dan daya pikir semata, tetapi malah lebih banyak ditentukan oleh kecerdasan emosional (EQ) dan kecerdasan Spiritual (SQ). Tentunya ada yang salah dalam pola pembangunan SDM selama ini, yakni terlalu mengedepankan IQ dengan mengabaikan EQ dan SQ. Kondisi demikian sudah harus di akhiri. Pendidikan harus diterapkan secara seimbang dengan memerhatikan dan memberi penekanan yang sama kepada IQ, EQ dan SQ.

Daniel Goleman merupakan penulis yang mengemukakan dan menemukan bahwa kecerdasan yang dibutuhkan manusia selain kecerdasan intelektual adalah kecerdasan emosi. Hal ini didasari oleh penelitiannya yang memberikan gambaran bahwa tingkat kecerdasan intelektual yang tinggi tidak menjadi satu-satunya andalan manusia untuk bias bertahan dan mengembangkan diri.

Pada dasarnya manusia harus bisa mempertahankan kelangsungan hidupnya dengan kualitas yang baik. Pencapaian kualitas hidup manusia yang optimal membutuhkan lingkungan dan interaksi di antara manusia itu sendiri. Lalu kecerdasan emosi yang kemudian akan melahirkan kecerdasan social bagi individu maupun 
dalam hubungannya dengan manusia lain menjadi penting. Inilah yang mendasari munculnya kecerdasan emosi.

Kecerdasan emosi menurut Goleman berada pada pusat-pusat otak purba. Pusat-pusat otak purba untuk emosi merupakan pelabuhan bagi ketrampilanketrampilan yang diperlukan untuk mengelola diri sendiri secara efektif dan untuk kecakapan social. Jadi, ketrampilan-ketrapilan ini mempunyai dasar dalam kisah evolusi manusia turun-temurun untuk bertahan hidup dan beradaptasi.

Penelitian Goleman membuktikan bahwa, tingkat kecerdasan emosi manusia tidak terikat dengan faktor genetis, dan tidak hanya dapat berkembang selama masa kanak-kanak. Berbeda dengan IQ yang sedikit perubahannya sesudah melewati masa remaja, kecerdasan emosi lebih banyak diperoleh lewat belajar, dan terus berkembang mutunya sepanjang hidup manusia tersebut. Dengan demikian, kecakapan seseorang dapat terus tumbuh seiring dengan pengalaman hidup yang diperolehnya. Seseorang makin lama bisa makin baik seiring dengan meningkatnya kemampuan mereka dalam menangani emosi dan impulsnya sendiri, dalam memotivasi diri dan dalam mengasah empati dan kecakapan social.

\section{METODE PENELITIAN}

Jenis penelitian ini adalah penelitian lapangan dengan pendekatan deskriptif kuantitatif dan kualitatif yang bersifat eksploratoris karena berusaha mengeksplorasi kegiatan jamaah Masjid kampus Arrobbaniyin UNISNU Jepara yang berkaitan dengan peningkatan kecerdasan emosional melalui salat fardu berjamaah. Peneliti dalam hal ini juga merupakan jamaah dan pengurus masjid kampus Arrobbaniyin yang mencoba meneliti peningkatan kecerdasan emosional melalui salat fardu berjamaah mahasiswa fakultas tarbiyah dan ilmu keguruan UNISNU Jepara.

Subjek Penelitian. Populasi dalam penelitian ini adalah semua mahasiswa Fakultas Tarbiyah dan IImu Keguruan UNISNU Jepara berjumlah sekitar 300 orang yang melaksanakan sholat fardu berjamaah pada waktu jamaah sholat duhur dan sholat Ashar. Di penelitian ini penulis mengambil sampel $10 \%$ dari populasi sehingga besar sampel penelitiannya sebanyak 30 jamaah dari jumlah populasi. Teknik penarikan sampelnya menggunakan metode purposive sampling atau sampel bertujuan .

Metode Pengumpulan Data. Teknik yang digunakan oleh peneliti dalam mengumpulkan data adalah :

Peningkatan Kecerdasan Emosional Melalui Sholat Fardu Berjamaah Mahasiswa Fakultas Tarbiyah dan Ilmu Keguruan di 
Pertama, Observasi di Masjid kampus Arrobbaniyin UNISNU Jepara. Untuk memperoleh data dan informasi yang diperlukan. Di sini penulis mengamati berbagai kegiatan salat fardu berjamaah di Masjid Arrobbaniyin Kampus UNISNU Jepara, kemudian dampak perilaku dari salat fardu berjamaah tersebut.

Kedua, Wawancara yaitu pengumpulan data melalui wawancara secara mendalam dan tanya jawab secara langsung kepada responden penelitian yang dapat memberikan keterangan kepada peneliti tentang pandangan, kesan dan pengalaman mereka selama aktif mengikuti salat fardu berjamaah masjid kampus Arrobbaniyin UNISNU Jepara.

Ketiga, Dokumentasi yaitu mengumpulkan buku-buku, arsip-arsip dan catatan yang ada hubungannya dengan penelitian dari studi pustaka, arsip pada Masjid Arrobbaniyin kampus UNISNU Jepara.

Keempat, Kuesioner, melakukan penyebaran kuesioner kepada sampel (jamaah Masjid Arrobbaniyin kampus UNISNU Jepara) untuk mengetahui tanggapan mereka mengenai hubungan salat fardu berjamaah dengan kecerdasan emosional.

Beberapa jenis teknik yang digunakan oleh peneliti di atas diperuntukkan agar bisa saling melengkapi sehingga tujuan penelitian dapat tercapai sesuai apa yang diharapkan penulis.

Data dan sumber data. Data yang diperlukan dalam penelitian ini meliputi: data primer yaitu data yang di dapat dari hasil observasi, angket dan wawancara mendalam kepada jamaah Masjid Arrobbaniyin kampus UNISNU Jepara khususnya jamaah yang dijadikan sampel serta beberapa pengurus Masjid kampus UNISNU sebagai sumber informasi. Data yang dicari adalah mengenai kegiatan peribadatan salat fardu berjamaah yang dilakukan oleh jamaah (sampel) penelitian yang berkaitan dengan peningkatan kecerdasan emosional melalui sholat fardu mahasiswa FTIK di masjid Arrobbaniyin kampus UNISNU Jepara. Sedangkan data sekunder dalam penelitian ini adalah data yang diperoleh dari buku-buku, majalah, arsip atau catatan-catatan masjid yang berhubungan dengan kegiatan peribadatan di Masjid Arrobbaniyin kampus UNISNU Jepara.

Teknik Analisis Data. Analisis data yang digunakan adalah analisis deskriptif kuantitatif dan kualitatif. Analisis data deskriptif yang digunakan untuk data yang diperoleh berupa kumpulan hasil kuesioner kemudian diperhitungkan mempergunakan teori distribusi frekuensi. Sedangkan analisis kualitatif digunakan untuk memperkuat hasil data yang diperoleh dari angket yang telah diperhitungkan 
dengan angka-angka atau berupa kode-kode dimana angka atau kode-kode tersebut penulis jelaskan melalui uraian deskriptif. Kedua analisis data tersebut kemudian dihubungkan dengan teori-teori yang disampaikan oleh para ahli atau para pakar Psikologi Barat maupun Psikologi Islam, sehingga diperoleh gambaran yang tepat mengenai peningkatan kecerdasan emosional melalui sholat fardu berjamaah mahasiswa FTIK di kampus Arrobbaniyin UNISNU Jepara.

\section{PEMBAHASAN}

\section{Kecerdasan Emosional dan Sholat Fardu Berjamaah di Masjid Kecerdasan Emosional}

Pengertian kecerdasan menurut kamus besar bahasa Indonesia adalah perihal cerdas, perbuatan mencerdaskan, kesempurnaan pengembangan akal budi (seperti kepandaian, ketajaman, akal pikiran. Konsep tersebut menghendaki kesempurnaan akal serta budi yang meliputi kepandaian dan optimalisasi berpikir. Sedangkan pengertian kecerdasan dalam arti umum merupakan suatu kemampuan yang dimiliki seseorang dalam memahami dan menyadari terhadap apa yang dialaminya naik melalui pemikiran, perbuatan, dan perkataan. Dalam berpikir biasanya seorang individu mengalami berbagai hal terhadap apa yang dialaminya sehingga ia mampu untuk merangkai, merumuskan, membandingkan, dan menganalogikan.

Adapun untuk bisa mengetahui tentang kecerdasan emosional bisa dipahami melalui beberapa penjelasan di bawah ini:

\section{Emosi}

Emosi merupakan pola perubahan kompleks yang mencakup komponenkomponen keterbangkitan faali, perasaan subjektif, proses kognitif serta reaksi-reaksi behavioral. Proses keterbangkitan faali dipicu oleh adanya rangsangan subjektif yang dialami seseorang dan biasanya disertai reaksi perilaku berupa ekspresi wajah, suara, sikap, atau reaksi lainnya. Menurut Atkinson dalam buku emosi, karya Darwis Hude, emosi adalah istilah yang merujuk pada keadaan dimana perubahan faali menyeluruh terjadi dengan intensitas yang amat kuat, sedangkan perasaan (feeling) berlangsung dengan intensitas lebih ringan.

\section{Kecerdasan Emosi}

Berikut ini pengertian kecerdasan emosi menurut beberapa ahli, diantaranya ialah sebagai berikut:

Peningkatan Kecerdasan Emosional Melalui Sholat Fardu Berjamaah Mahasiswa Fakultas Tarbiyah dan Ilmu Keguruan di 
a. Daniel Goleman, menurutnya kecerdasan emosi berada pada pusat-pusat otak purba. Pusat-pusat otak purba untuk emosi merupakan pelabuhan bagi ketrampilan-ketrampilan yang diperlukan untuk mengelola diri sendiri secara efektif dan untuk kecakapan social. Jadi, ketrampilan-ketrapilan ini mempunyai dasar dalam kisah evolusi manusia turun-temurun untuk bertahan hidup dan beradaptasi.

b. Peter Salovy dan John Mayer, kecerdasan emosi adalah kemampuan untuk memonitor perasaan diri sendiri dan orang lain, kemampuan untuk membedakannya, dan kemampuan untuk menggunakan informasi ini untuk memandu pemikiran dan tindakan dirinya.

c. Cooper dan Sawaf, menurut pendapat mereka kecerdasan emosional adalah kemampuan merasakan, memahami, dan secara selektif menerapkan daya dan kepekaan emosi sebagai sumber energi dan pengaruh yang manusiawi. Didalam kecerdasan emosi menuntut penilikan perasaan, untuk belajar mengakui, menghargai perasaan diri dan orang lain. Selain itu, mampu menanggapinya dengan tepat, menerapkan secara efektif energi emosi dalam kehidupan seharihari.

\section{Komponen pendukung kecerdasan emosional}

Kecerdasan emosional dan intelektual merupakan kecerdasan yang saling terkait dan melengkapi. Seperti misalnya, bila seseorang memiliki IQ yang tinggi namun ia tertutup dengan lingkungan sekitar, kesuksesannya akan terhambat. Pada kasus ini berarti individu memiliki tingkat kecerdasan emosional yang rendah.

Goleman dalam risetnya mengenai kecerdasan emosional menemukan lima komponen pendukung kecerdasan emosional yang tentu saja dapat dijadikan oleh individu bila ingin sukses, yakni :

Pertama, Mampu mengenali perasaan sendiri. Maksud dari mengenal perasaan sendiri adalah kemampuan dalam melihat perasaan diri sendiri dari waktu ke waktu. Dalam tahap ini diperlukan adanya pemantauan atas perasaan secara berkesinambungan, agar muncul wawasan kejiwaan dan pemahaman tentang diri Kesadaran diri adalah kemampuan untuk mengenali diri sendiri. Ini adalah kunci dari kecerdasan emosional (EQ) Anda. Kesadaran diri meliputi kemampuan diri Anda untuk mengenali dan mengatur emosi diri sendiri yang dapat mempengaruhi pikiran dan perilaku Anda serta kemampuan Anda. Ketika Anda memahami emosi Anda, akan lebih mudah bagi Anda untuk mengakui dan mengendalikan emosi Anda dan mencegah Anda dari perasaan berkuasa Anda sendiri. Anda juga lebih percaya diri 
karena Anda bisa mengontrol emosi Anda. Menjadi sadar diri akan membuat Anda selalu bersikap jujur dalam menilai diri sendiri dan lebih tahu kekuatan dan kelemahan diri Anda sehingga dapat bekerja sesuai dengan kemampuan diri untuk mencapai hasil yang lebih baik bagi diri Anda sendiri maupun bagi orang lain.

Kedua, Pengaturan diri. Pengaturan diri adalah kemampuan untuk mengatur diri sendiri dan ngendalikan emosi. Jika Anda mampu mengelola dan mengendalikan emosi Anda, akan menjadi lebih mudah bagi Anda untuk berfikir sebelum bertindak sehingga bisa mencegah Anda dari membuat keputusan yang ceroboh. Memiliki kemampuan dalam pengaturan diri akan membuat Anda mampu mengubah emosi negatif Anda menjadi emosi yang positif dan produktif.

Ketiga, Motivasi. Memiliki kecerdasan emosional (EQ) yang tinggi berarti Anda mampu memanfaatkan emosi Anda untuk memotivasi diri Anda dalam mengambil tindakan yang tepat, melakukan tindak lanjut, dan bekerja kearah pencapaian tujuan Anda. Bila Anda memiliki kecerdasan emosional (EQ) yang tinggi Anda cenderung termotivasi, produktif dan efisien dalam segala hal yang Anda lakukan. Anda juga selalu menggunakan emosi Anda secara positif untuk mengambil tindakan yang tepat atau bahkan bertahan saat menghadapi kesulitan.

Keempat, Empati. Empati adalah kemampuan untuk membedakan perasaan orang lain, memahami emosi mereka dan memanfaatkan pemahaman yang berhubungan dengan orang lain secara efektif. Orang yang memiliki empati biasanya sangat baik dalam mengelola hubungan, memperbaiki komunikasi, membangun kepercayaan dan berhubungan dengan orang lain.

Kelima, Keterampilan sosial. Memiliki keterampilan sosial yang baik berarti Anda tahu bagaimana cara mengembangkan dan mempertahankan hubungan yang baik, berkomunikasi dengan jelas, menginspirasi dan mempengaruhi orang lain, bekerja dengan baik dalam tim dan tahu bagaimana caranya mengelola dan mengatasi konflik.

Tiga komponen kecerdasan emosional (EQ) yang pertama disebut kemampuan intrapersonal, yakni kemampuan Anda untuk mengetahui dan mengelola diri sendiri. Sedangkan komponen keempat dan terakhir adalah kemampuan interpersonal, yakni kemampuan Anda untuk berinteraksi dan bergaul dengan orang lain. Semakin baik kemampuan intrapersonal Anda, semakin mudah untuk mengekspresikan keterampilan interpersonal Anda. Menguasai keterampilan ini akan

Peningkatan Kecerdasan Emosional Melalui Sholat Fardu Berjamaah Mahasiswa Fakultas Tarbiyah dan Ilmu Keguruan di 
membuat Anda hidup lebih baik, lebih bahagia dan lebih sukses dalam hidup. Ini kunci kesuksesan dari kecerdasanemosional.

\section{Sholat fardlu berjamaah di masjid}

Masjid merupakan rumah ibadah bagi umat Islam dengan tujuan utamanya adalah pelaksanaan salat fardu berjamaah disamping kegiatan sosial keagamaan lainnya. Namun sangat disayangkan banyak masjid yang dibangun dengan susah payah, dana milyaran rupiah, dalam jangka waktu lama dan setelah berdiri kondisinya cukup memprihatikan seperti shaf-shaf salat berjamaah dalam pelaksanaan salat berjamaah tidak selalu penuh terisi dan jamaahnya loyal memakmurkan masjid juga sangat sedikit.

Di kampus UNISNU Jepara terdapat sebuah masjid yang mempunyai jamaah tetap dan banyak serta mempunyai loyalitas yang tinggi untuk komitmen selalu salat fardu berjamaah di masjid. Masjid tersebut adalah Masjid Arrobbaniyin yang terletak di tengah-tengah kampus UNISNU Jepara. Masjid ini dikelola oleh pimpinan UNISNU Jepara dan dibimbing langsung Yayasan UNISNU Jepara. Uniknya walaupun identik dengan masjid kampus namun mempunyai daya tarik tersendiri karena jamaah yang datang untuk salat fardu berjamaah bukan hanya dari kalangan civitas akademika kampus pihak pimpinan, dosen, karyawan dan mahasiswa tetapi dari masyarakat stempat juga ikut berjamaah di masjid kampus Arrobbaniyin ini. Berdasarkan informasi dari pengurus Masjid kampus Arrobbaniyin UNISNU Jepara dan hasil observasi penulis di lapangan, jumlah jamaah yang melaksanakan salat fardu berjamaah di Masjid kampus kurang lebih 800 orang pada saat sholat berjamaah waktu dhuhur dan sholat berjamaah waktu Ashar, dari 800 orang tersebut diperkirakan 300 orang dari mahasiswa Fakultas Tarbiyah dan IImu Keguruan UNISNU Jepara, Para jamaah yang terdiri dari para pimpinan, dosen, karyawan, mahasiswa dan masyarakat mereka semua aktif membaur menjadi satu dalam salat berjamaah.

Hasil penelitian tentang peningkatan kecerdasan emosional melalui sholat fardu barjamaah mahasiswa Fakultas Tarbiyah dan IImu Keguruan UNISNU Jepara dapat di liahat pada tabel di bawah ini..

\section{REKAPITULASI HASIL PENINGKATAN KECERDASAN EMOSIONAL MELALUI SHOLAT FARDU BERJAMAAH MAHASISWA FTIK UNISNU}

Dari data yang telah diambil, dapat peneliti analisis mengenai peningkatan kecerdasan emosional melalui sholat fardu berjamaah mahasiswa Fakultas Tarbiyah 
dan IImu Keguruan di masjid kampus Arrobbaniyin UNISNU Jepara dengan indikatorindikator pembahasan sebagai berikut:

\section{Mampu mengendalikan dorongan nafsu dunia}

Berdasarkan keterangan pada tabel 1, pertanyaan kepada responden mengenai "mampu mengendalikan dorongan nafsu duniawi" terlihat jumlah pendapat tetinggi yang mengatakan "ya" adalah sebanyak $66 \%$ atau 20 suara dari 30 jamaah.

Berdasarkan jawaban responden ini membuktikan bahwa seseorang yang sering melaksanakan ibadah salat fardu berjamaah dengan baik dan benar akan berpengaruh terhadap perubahan mental perilakunya menjadi lebih baik, dimana semua itu akan tercermin di dalam perilaku kehidupan sehari-harinya yang mampu mengendalikan dorongan nafsu duniawi (qana'ah, zuhud, wara). la akan berhati-hati dalam bersikap dan berbuat (bertindak ) karena ia merasa setiap perbuatannya akan dilihat Allah atau dengan kata lain setiap perbuatan itu akan diminta pertanggung jawabkannya pada hari akhir nanti.

Komitmennya yang kuat dalam melaksanakan takwa kepada Tuhannya membuat mahasiswa hidupnya merasa lebih tenang dan barakah. Mahasiswa Fakultas Tarbiyah dan IImu Keguruan UNISNU Jepara yang ekonominya rendah sebagaian besar mereka melaksanakan kuliah sambil bekerja. Ada yang bekerja di home industri mebel Jepara, ada yang membantu orang tuanya bertani di sawah, dan masih banyak lagi.

Penulis juga melakukan wawancara dengan mahasiswa yang ekonomi orang tuanya termasuk kaya. Namun, beliau tetap aktif salat fardu berjamaah. sudah mendarah daging atau menjadi suatu ikatan di dalam diri atau jiwa, sehingga apabila sudah masuk azan tanda dari salat fardu itu sudah tiba beliau pun bergegas untuk memenuhi panggilan azan tersebut agar bisa melaksanakan salat fardu berjamaah di mesjid. karena kata beliau ketika kita mendengar azan dan kita tdak memenuhi salat fardu berjamaah di mesjid maka di dalam hati ini timbul perasaan gelisah, hati tidak tenang karena merasa ada yang kurang terhadap apa yang dilakukan. Manfaat yang beliau rasakan efeknya dari salat fardu berjamaah selain memenuhi syariat agama yaitu dengan salat fardu berjamaah beliau merasa ketenangan hati dan stress pun hilang setelah menunaikan salat fardu berjamaah.

Sementara untuk responden yang menjawab pertanyaan kadang-kadang "mampu mengendalikan dorongan nafsu duniawi" terlihat jumlah suara 10 orang atau 34\% dari 30 jamaah Mesjid Arrobbaniyin kampus UNISNU Jepara. Prosentase 
ini menunjukkan bahwa seseorang itu walaupun sudah merasa beriman dan menjalankan syariat agama tidak menutup kemungkinan tidak konsekuen atau tidak istiqomah dalam ketaatan. Namun, semua itu wajar, apalagi status mereka sebagai mahasiswa dan hal itu juga yang membuktikan perkataan Rasulullah saw yang artinya "seseorang muslim paginya mengaku beriman tetapi sore harinya ia bisa tidak beriman". Perkataan Rasulullah lainnya menyebutkan "keimanan seseorang itu kadang bisa naik dan juga bisa turun, atau kata lain bisa berubah-ubah".

\section{Mampu memotivasi diri sendiri}

Pertanyaan kepada responden mengenai "mampu memotivasi diri sendiri (niat bersungguh-sungguh, ikhlas)" dengan pendapat tertinggi adalah $86 \%$ suara atau 26 orang dari 30 jamaah menyatakan ya. Ini menandakan bahwa ada hubungan antara salat fardu berjamaah dengan kecerdasan emosional khususnya yang berkaitan dengan mampu memotivasi diri sendiri.Salat fardu berjamaah mampu membangkitkan motivasi diri para jamaah, apabila seorang jamaah telah terpikat dengan kegiatan salat fardu berjamaah maka dia akan selalu termotivasi untuk berdiri, bergerak dan berangkat menuju mesjid walau terkadang mencuri waktu ditengah kesibukan sebagai mahasiswa, walau badan terkadang dirasakan masih sakit dan seribu persoalan masih membebeni otak.

Berdasarkan hasil observasi dari penulis ada salah seorang jamaah dengan inisial $A B$ Menurut mahasiswa $A B$ ini (inisial) meskipun kegiatan mahasiswa banyak ketika waktu salat fardu zuhur masuk maka dia segera meninggalkan kegiatannya Namun, baginya dengan salat fardu berjamaah adalah suatu rangkaian motivasi yang berurutan dalam lima waktu yaitu ketika masuk waktu shubuh ini menandakan awal pekerjaan segera dimulai dari waktu salat fardu subuh inilah terpancar doa dan harapan semoga hari ini mendapatkan kemudahan dalam mencari ilmu, kemudian masuk waktu salat fardu zuhur disini kembali terucap rasa syukur atas waktu yang diberikan Allah SWT karena masih bisa mencari ilmu di kampus UNISNU.

Sementara untuk responden yang menyatakan kadang-kadang sebesar 13,4 \% ini mengindikasikan bahwa secara alamiah, manusia, psikologis motivasi manusia itu bisa naik dan bisa turun seperti urusan kegiatan mahasiswa dan kadang juga dalam beribadah namun hal ini manusiawi karena walau ada kemalasan tetap saja para mahasiswa jemaah Mesjid Arrobbaniyin kampus UNISNU Jepara dengan sebagai kekurangan selalu aktif melakukan kegiatan salat fardu berjamaah.

\section{Mampu bertahan dalam menghadapi cobaan}


74 | Jurnal Tarbawi Vol. 16. No. I. Januari - Juni 2019

Pertanyaan kepada responden mengenai "mampu bertahan dalam menghadapi cobaan (sabar, istiqomah)". Dengan pendapat tertinggi adalah Ya sebanyak $80 \%$. Ini menandakan bahwa ada hubungan antara salat fardu berjamaah dengan kecerdasan emosional yang indikatornya mampu bertahan dalam menghadapi cobaan.Kondisi ini membuktikan bahwa seseorang yang sering mengamalkan salat fardu berjamaah akan memberikan stimulan atau vitamin agar mampu bertahan dalam menghadapi cobaan. Semua itu ada peran sabar dan sikap istiqomah seseorang dalam bertakwa, karena menurut ajaran Islam bahwa seseorang muslim sebelum mengaku beriman maka ia akan di uji Tuhan keimanannya, dan apabila lulus maka ia kan di naikkan derajatnya. Untuk itu seseorang hendaknya membekali diri agar mampu menghadapi setiap cobaan yang datang salah satunya dengan rajin melaksanakan salat fardu. Sesuai apa yang dianjurkan Tuhan dalam QS AI Baqarah :153 artinya "minta pertolonganlah dengan Allah yaitu dengan cara sabar dan salat fardu".

\section{Tidak melebih-lebihkan kesenangan}

Pertanyaan kepada responden mengenai "perilaku yang tidak belebih-lebihkan kesenangan terhadap apa yang sudah di dapatkan selama ini (syukur, tawadhu) "dengan pendapat terbanyak adalah sebanyak 86,6 \% atau 26 orang menyatakan ya. Mahasiswa FTIK yang menjalankan sholat fardu berjamaah atau responden yang sudah rutin mengamalkan salat fardu berjamaah seperti apa yang ditemui penulis bahwa mereka walaupun termasuk kelompok remaja, di mana remaja banyak gangguan dari luar lingkungan yang bersifat hura-hura, justru malah mereka bisa mengendalikan ego bersenang-senangnya atau kata lainnya mereka lebih tawadhu (rendah hati).

Keadaan yang lebih baik tersebut mereka tetap istiqomah menjalankan perintah agama yakni tetap melakukan salat fardu berjamaah, sikap seperti inilah mungkin dapat dikatakan seseorang itu sebagai hamba yang tetap ingat melakukan syukur kepada TuhanNya. Kalau kita analisis dalam pendekatan psikologi inilah yang di namakan kecerdasan emosional menurut Daniel Goleman maupun Imam Ghazali ; bahwa salah satu ciri kecerdasan emosional yang dimiliki seseorang adalah perilakunya mampu tidak melebih-lebihkan terhadap apa yang sudah di dapatkan atau diperoleh saat ini. Kata lainnya menurut istilah Imam Ghazali orang tersebut mampu bersikap syukur dan tawadhu.

Sedangkan, untuk responden yang menjawab "kadang-kadang" sekitar 4 orang

Peningkatan Kecerdasan Emosional Melalui Sholat Fardu Berjamaah Mahasiswa Fakultas Tarbiyah dan Ilmu Keguruan di Masjid Kampus Ar-Robbaniyin Unisnu Jepara | Mufid dan Alex Yusron Al-Mufti| < 
atau $13,4 \%$ dari total responden menunjukkan keadaan ini bagian dari sebuah proses waktu keimanan seseorang dalam memahami ajaran agamanya. Dimana suatu saat nanti apabila tetap istiqomah melaksanakan ajaran syariat dan menambah pemahaman agama Islam secara mendalam insya Allah akan bisa mengendalikan nafsu atau ego dirinya.

\section{Mampu mengatur suasana hati}

Pertanyaan kepada responden mengenai" responden yang sering salat fardu berjamaah dapat mengatur suasana hati (jiwa menjadi tenang, gembira, pemaaf, malu, jujur)". Hasil prosentasi responden yang mengatakan "ya" sebanyak 25 orang atau 83,3 \%. Hal ini menunjukkan seseorang melaksanakan salat fardu berjamaah di mesjid itu mampu membuat tenang hati seseorang, tidak stres, lebih lembut hatinya (pemaaf), menghilangkan kegelisahan.

Mengapa keadaan di atas bisa terjadi dalam diri atau jiwa seseorang? Karena menurut kesaksian penulis mahasiswa FTIK yang sholat berjamaah di masjid Arrobbaniyin kampus UNISNU Jepara, ternyata dapat merilekkan pikirannya ya sebelumnya sumpek atau bahkan kesibukannya, tugas maupun problem yang sebelumnya tidak terpecahkan ternyata setelah selesai melaksakan salat fardu ditemukan jalan keluarnya dan juga pikiran yang kalut pun akhirnya dapat reda, kondisi ini berkesesuaian dengan firman Tuhan QS. Ar-Rad :112 yang artinya "hanya dengan mengingat Allah hati akanmenjadi tenang".

Kondisi inilah yang disebut oleh para peneliti kejiwaan yang mengatakan salat fardu itu terdiri dari beberapa aspek, diantaranya aspek rileksasi karena melakukan gerakan seperti olah raga sehingga membuat badan sehat dan rileks, aspek meditasi karena dalam salat fardu mengandung aspek meditasi dimana adanya pemfokusan pikiran dalam satu titik pikiran yang dalam salat fardu kita disuruh khusyu dan thuma'ninah yang semua itu pada saat salat fardu kita hanya diperintahkan fokus menghadap Allah Swt.

Sementara untuk responden yang menjawab "kadang-kadang" sebanyak 5 orang atau 16, $7 \%$, angka tersebut menunjukkan masih terdapat jamaah yang masih belum merasakan atau menikmati secara penuh tentang efek dari mendekatkan diri dengan Tuhan khususnya dalam melaksanakan salat fardu berjamaah. Kondisi itu bisa juga disebabkan salah satunya karena belum bisa selalu melakukan salat fardu dengan khusyu dan nyambung (shilah) dengan Tuhan atau bisa juga karena kemampuan pemahaman ilmu batin di dalam dirinya belum mantap dalam memahami 
ajaran Islam. Tetapi kondisi ini menurut penulis masih wajar bila terdapat keadaan kadang- kadang karena dalam melaksanakan ajaran agama Islam ini perlu proses, latihan, bertahap jika di dalam konteks metode sufi terdapat beberapa tingkatan atau maqam seseorang dalam proses pendekatan diri dengan Tuhannya.

\section{Menjaga agar beban stress tidak melumpuhkan kemampuan berpikir}

Pertanyaan kepada responden mengenai "salat fardu berjamaah mampu menjaga agar beban stress tidak melumpuhkan kemampuan berpikir (ridha)". Responden yang menjawab "ya" sebanyak 26 orang atau 86,67\%. Kondisi ini menunjukkan salat fardu berjamaah memang mampu membuat diri seseorang terhindar dari stress. Untuk itu tidak salah bila para Psikolog Muslim seperti Usman Najati merumuskan salat fardu merupakan bagian salah satu dari terapi mengatasi stress. Karena dengan salat fardu seseorang biasanya dapat merasakan ketenangan hati atau melahirkan kebahagiaan, ungkap Dzahabi.

Sebenarnya kecerdasan emosional dengan salah satu cirinya "mampu menjaga agar beban stress tidak melumpuhkan kemampuan berpikir dapat kita setarakan dengan ridha alam konsep kecerdasan Imam al-Ghazali. Mengapa? Karena apabila seseorang sudah mampu bersikap ridha terhadap setiap ketentuan Tuhan yang menimpa dirinya. Maka, hidupnya di jamin akan mendapatkan ketenangan dan ketentraman hati tanpa di liputi rasa gelisah apalagi kegalauan hati. Orang yang sudah terbiasa ridha terhadap ketentuan takdir Tuhan dalam sudut pandang ilmu kesehatan juga berdampak positif terhadap kesehatan tubuhnya karena apapun takdir Tuhan ia akan berusaha selalu senang, gembira, bahagia ikhlas menerimanya.

Sementara untuk responden yang menjawab "kadang-kadang" sebanyak 4 orang atau 13, $33 \%$ dari total responden. Fakta di lapangan ini memang tidak bisa dihindarkan karena setiap orang berbeda-beda kemampuannya dalam menyikapi permasalahan hidup, namun dengan istiqomah melakukan salat fardu dan ditambah dengan belajar ajaran Islam secara menyeluruh jamaah tersebut bisa saja menjadi lebih baik. Dari kesimpulan ini selain mengamalkan rutin salat fardu berjamaah hendaknya kita juga agar berusaha dapat menerima dengan ikhlas dan ridha dalam menghadapi setiap persoalan kehidupan karena terkadang apa yang kita inginkan di dalam hidup ini tak sesuai dengan harapan dan bagi kita orang beriman dan bertakwa agar menganggap semua itu sudah qadar Allah swt sehingga kita terbebas dari

Peningkatan Kecerdasan Emosional Melalui Sholat Fardu Berjamaah Mahasiswa Fakultas Tarbiyah dan Ilmu Keguruan di 
penyakit fisik dan batin.

\section{Berempati dan Berdoa}

Pertanyaan kepada responden mengenai "Berempati (kasih sayang, suka menolong sesama, suka berbagi/dermawan) dan berdoa (meminta pertolongan kepada Allah". Responden yang menjawab "ya" sebanyak 23 orang atau 76, 6 \%. Kondisi ini menunjukkan bahwa dengan salat fardu berjamaah yang biasa bertemu atau berinteraksi dengan banyak orang akan menumbuhkan sikap di dalam diri rasa empati, kepedulian kasih sayang, suka bantu membantu, cerdas secara sosial. Karena dengan selalu berjamaah seperti terasa keluarga sendiri tutur jamaah, ikatan emosional lumayan terbangun kuat. Silaturahmi yang dilakukan dengan berjamaah disana terasa lebih nyaman, akrab. Sehingga seseorang yang salat fardu berjamaah di mesjid tersebut akan terasa ruh jihadnya. Yang jelas kata Rasulullah SAW "mukmin itu dengan mukmin yang lainnya adalah saudara, dan hadist lainnya menyebutkan "mukmin itu seperti satu bangunan/tubuh, maka apabila satu mengalami sakit dan lainnya pun akan mengalami sakit”.

\section{SIMPULAN}

Adanya peningkatan kecerdasan emosional melalui sholat fardu berjamaah mahasiswa Fakultas Tarbiyah dan IImu Keguruan di masjid kampus Arrobbaniyin UNISNU Jepara hal ini dibuktikan dengan adanya data dari hasil kuisioner dari 30 jamaah (responden) yaitu : Mampu mengendalikan dorongan nafsu duniawi dengan pendapat tertinggi adalah $66 \%$ menyatakan ya dan $34 \%$ menyatakan kadang-kadang. Memotivasi diri sendiri dengan pendapat tertinggi adalah $86,6 \%$ menyatakan ya dan $13,4 \%$ menyatakan kadang-kadang. Mampu bertahan dalam menghadapi cobaan dengan pendapat tertinggi adalah $80 \%$ menyatakan ya dan $20 \%$ menyatakan kadangkadang. Tidak melebih-lebihkan kesenangan dengan pendapat tertinggi adalah $86,6 \%$ menyatakan ya dan $13,4 \%$ menyatakan kadang-kadang. Mampu mengatur suasana hati dengan pendapat tertinggi adalah 83,3\% dan 16,7\% menyatakan kadang-kadang. Menjaga agar beban stress tidak melumpuhkan kemampuan berpikir dengan pendapat.tertinggi adalah $86,67 \%$ menyatakan ya dan $13,33 \%$ menyatakan kadang-kadang.Berem dan berdoa dengan pendapat tertinggi adalah 76,6\% menyatakan ya dan $23,4 \%$ menyatakan kadang-kadang. 
78 | Jurnal Tarbawi Vol. 16. No. I. Januari - Juni 2019

\section{DAFTAR PUSTAKA}

Abd. Wahab dan Umiarso, (2010) Kepemimpinan Pendidikan dan Kecerdasan Spiritual, Jogjakarta: Ar-Ruzz Media

Al. Tridhonanto, (2009) Melejitkan Kecerdasan Emosi (EQ) Buah Hati, Jakarta: PT Gramedia

Alsa, Asmadi, "Motivasi Belajar" dalam Materi mata kuliah Psikologi Pendidikan Islam Kontemporer, Mahasiswa S3 Psikologi Pendidikan Islam Universitas Muhammadiyah Yogyakarta 2017/2018.

Amie Primarni dan Khairunnas, (2016) Pendidikan Holistik Format Baru Pendidikan Islam Membentuk Karakter Paripurna, Jakarta Selatan: PT AL-MAWARDI PRIMA

Arikunto, Suharsimi. (2002) Metode penelitian, Jakarta: Rineka Cipta

Bahnasi, Muhammad. (2007)Salat fardu sebagai terapi psikologi. Bandung: Mizania Daniel Goleman, (2000) Kecerdasan Emosional, Jakarta: PT Gramedia Pustaka Darwis, M. (2006) Emosi Penjelajahan Religio-Psikologis Tentang Emosi Manusia di dalam Al Qur'an. Jakarta: PT: Gelora Aksara Pratama

Ghazali, Ihya' 'Ulum al-Din, Kairot Dar Ihya' al-Kutub al-'Arabiyah, t.th.

Mubin. (2015) ESQ Dalam Perspektif Tasawuf Al-Ghazali. Banjarmasin: Antasari press

Poerwadarminta. (1976) Kamus Umum Bahasa Indonesia. Jakarta: Balai Pustaka

Salim, Ahmad Husain. (2009) Menyembuhkan Penyakit Jiwa dan Fisik. Jakarta: Gema Insani

Shihab, Muhammad Quraish, (2008) Wawasan al-Qur'an, Tafsir Maudhu'l atas Berbagai Persoalan Umat, Bandung: Penerbit Mizan (2005) Membumikan al-Qur'an, fungsi dan peran Wahyu dalam Kehidupan Masyarakat, Bandung, Mizan

Sholeh, Moh. (2008) Bertobat Sambil Berobat. Jakarta: Hikmah 